\title{
ARCHAEOLOGICAL AND CONTEMPORARY HUMAN HAIR COMPOSITION AND MORPHOLOGY
}

\author{
COMPOSICIÓN Y MORFOLOGÍA DE CABELLO HUMANO \\ ARQUEOLÓGICO Y CONTEMPORÁNEO
}

\author{
Josefina Mansilla ${ }^{1}$, Pedro Bosch ${ }^{2}$, María Teresa Menéndez ${ }^{1}$, Carmen Pijoan ${ }^{1}$, Carlos Flores ${ }^{2}$, \\ María del Carmen López ${ }^{3}$, Enrique Lima ${ }^{2 *}$, and Ilán Leboreiro ${ }^{1}$
}

\begin{abstract}
Contemporary and mummy hair samples are characterized and compared, using modern chemical and physical characterization methods. It is found that in cave conditions mummy hair can be preserved even if it interacts with environmental dirt or soil, X-ray diffraction and infrared spectroscopy results. Hair is an ion exchanger and the exposure to earth and water can facilitate the interaction of some elements with hair as shown by X-ray fluorescence, energy dispersive spectroscopy and neutron activation analysis. Post mortem degradation is detected through the reaction of cystine and through the partial collapse of the scale arrangement. The mummy hair scales become less ordered and the hair surface less smooth, such features were clearly observed by scanning electron microscopy and atomic force microscopy. The presented interdisciplinary results show that alteration of hair initiates in the core but scales are often well preserved. The features found in mummy hair suggest that the correlation between chemical composition and health or nutrition of ancient people should be carefully evaluated due to environmental contamination.
\end{abstract}

Key words: Hair, mummy, human, scalp, cuticle, cortex, keratin.

\begin{abstract}
Muestras de pelo de momia y también contemporáneo se compararon y caracterizaron por métodos espectroscópicos y fisicoquímicos. Se encontró que el pelo de la momia en una cueva se puede conservar, incluso si interactúa con el medio ambiente o la suciedad del suelo. El cabello es un intercambiador de iones y la exposición a la tierra y el agua puede facilitar la interacción de algunos elementos con el pelo como se mostró por fluorescencia de rayos $X$, espectroscopía de energía dispersiva y análisis por activación neutrónica. La degradación post mortem se detecta a través de la reacción de la cistina y por el colapso parcial de la disposición de escamas. Las escamas del cabello de momia están menos ordenadas y la superficie del pelo menos lisa, características que se observaron claramente por microscopía electrónica de barrido y microscopía de fuerza atómica. Las características que se encuentran en el cabello de la momia sugieren que la correlación entre la composición química y la salud o la nutrición de los pueblos antiguos deben evaluarse cuidadosamente, debido a la contaminación del medio ambiente.

Palabras claves: pelo, momia, humano, cuero cabelludo, cutícula, corteza, queratina.
\end{abstract}

In human body, scalp hair is one of the more resistant soft tissues to decay and disappear after death (Bertrand 2003). Research has established that in frozen or arid environments the amino acids present in hair are not altered even after thousands of years. Thus, it is possible to extract isotopic information to investigate the diet and geographical origin of individuals (Macko 1998). Hair is a very valuable source of bio-archaeological, biographical, lifestyle and forensic information, such as sex, social status, depending on age and culture. Hair structure is sensitive to variations in the internal equilibrium of the corresponding person (Thibaut 2005). Acute and/ or chronic diseases, diet, work habits and exposure to environmental conditions can cause morphological and structural alterations (Nowak 1996; DumestreToulet 2002). The study of hair is crucial if drug consumption, dietary prediction, or contamination with heavy metals intra vitam have to be established (Aufderheide 2002).

Hair is made up of three main layers: the cuticle (outermost component), the cortex (or inner sheath), and the medulla (or central core). The hair cuticle originates from a single-layered epithelium and is made up of a large number of keratin overlapping scales. The epicuticle is a semi-permeable membrane

1 Dirección de Antropología Física, Instituto Nacional de Antropología e Historia, Gandhi s/n, Polanco, 11560 México D.F., México.

2 Instituto de Investigaciones en Materiales, Universidad Nacional Autónoma de México, Circuito Exterior, Ciudad Universitaria, 04510 México D.F., México. *Corresponding author: lima@iim.unam.mx.

3 Instituto Nacional de Investigaciones Nucleares, A. P. 18-1027, 11801 México D.F., México. 
which surrounds each cuticle cell and forms the outer surface of the hair. The cortex comprises the main part of the hair fibre. Cortical cells consist of spindle shaped fibrous structures termed macrofibrils, nuclear remnants and pigment granules. They are strongly keratinized cells arranged longitudinally. The medulla or central core consists of keratinized and often shrunk cell groups with intercellular spaces along the fibre axis. The pigment granules may be found scattered throughout the cortex and the medulla.

Post mortem alterations, such as heavy metal contaminations or taphonomic modifications of hair color, have also been described; such alterations can be identified by various physical and chemical techniques (Du et al. 1996; Monteiro 2005; Meaglia 2005; Sandford 1993). Hair MtDNA has been shown to survive after degradation in a soil burial environment, therefore its analysis is a reliable source for migration patterns, identifying missing persons, war casualties, mass disaster victims and victims of crime (Gilbert 2006). Even, in cosmetic industry, preservation, deterioration and morphology of hair are often a problem. However, after death, decay of hair, decay and deterioration with time, in different contexts, are topics that have not been thoroughly studied.

In this work, we compare mummy and contemporary hair to determine the alterations due to time and to understand tissue characteristics and behavior in both past and present populations. We selected Chihuahua mummies as they have maintained their hair and they were deposited in caves whose dry atmosphere did not change allowing the natural mummification and preservation of the corpses. Our purpose is to show how modern chemical and physical techniques may provide a new insight on the characterization. Only through such measurements the mechanisms of hair deterioration can be understood.

\section{Experimental}

\section{Samples}

Four precolumbian natural mummies of the Dirección de Antropología Física del Instituto de Antropología e Historia (INAH) collection, in Mexico city, were chosen for this investigation. Three of them were found in the cave La Ventana, located in the Tarahumara region of Norogachic,
Southwest of the Estado de Chihuahua. The Oxford Radiocarbon Accelerator Unit radiocarbon date from one theeth of one of the cave's mummies was recently obtained, $912 \pm 30 \mathrm{BP}$. The fourth mummy, child from la Ventana (classified as F2 and labeled as ChildVentF2 in this work), is from the North of the country although the precise location is unknown. The archaeological evidence from this region, implies that highly variable combinations of population aggregation, agricultural dependence, and degrees of sedentism were present. The climate is dry to semi-arid. The hunter-gatherer groups in these desert areas were small, later they developed farming with corn domestication.

Two of the La Ventana mummies are female adults and the other two are children. For comparison purposes, two samples of contemporary young adults, female and male, who did not use any cosmetics for hair, are included. Lastly, two samples of earth associated to the mummified corpses were taken. Hair (a few filaments for each sample) was obtained from the occipital region avoiding any possible contamination. All studies were made using the closest centimeters to the scalp. Samples were stored in sterilized plastic containers.

Samples were labeled as follows:

- FemCont=female contemporary individual,

- MaleCont=male contemporary individual,

- ChildVentIV and ChildVentF2 = children from

La Ventana (classified as La Ventana IV and F2, respectively),

- FemAdMuVentV and FemAdMuVentII = female adult mummies from La Ventana $\mathrm{V}$ and La Ventana II, respectively.

The hair samples were obtained from the back of the skull with sterile tweezers wearing disposable gloves and masks. The samples were stored and transported in sealable plastic bags. Nevertheless, these samples have been under anthropological studies prior to the decision to undertake these analysis.

\section{Characterization techniques}

We have chosen to characterize first the elemental composition of the samples, second to identify the crystalline compounds and third to study the morphology. In the first step, $\mathrm{X}$ ray fluorescence technique was used as it is a bulk characterization. We compare these results with those provided by neutron activation analysis and 
energy dispersive spectroscopy. As each method is based on different physical phenomena, they are complementary. Knowing the elemental composition, the crystalline could be identified. Hair is not a crystalline compound and therefore if $\mathrm{X}$-ray diffraction peaks are observed they must be due to "external" contributions. The microscopies are also complementary. The scanning electron microscopy is obtained in vacuum and after covering the samples with a conductor material but the atomic force microscopy does not require vacuum and the observation is made in situ. It has a much higher resolution although the field depth is lower. We used atomic force microscopy to observe the hair cells. To identify the organic species present in the sample, infrared spectra were obtained.

A spectrometer Siemens, SRS 303 was used for X-Ray Fluorescence studies (XRF). Elements lighter than fluorine are not detected with this method.

Neutron Activation Analysis is a much more precise method (NAA) which provides percentages of trace elements. It has to be performed in a nuclear reactor. The samples were studied at the nuclear reactor of Salazar with the SIFCA irradiation system of the Instituto Nacional de Investigaciones Nucleares (ININ) at Salazar, Mexico.

Crystalline compounds were identified with X-ray diffraction (XRD). XRD patterns were obtained with a Bruker AXS D8 advance diffractometer coupled to a copper anode X-ray tube. The experimental patterns are conventionnally compared to those reported in the Joint Committee of Powder Diffraction Standards (JCPDS).

These results may be compared with the elemental analysis obtained by Energy Dispersive Spectroscopy (EDS) which provides local analyses. This technique is associated to the Scanning Electron Microscope (SEM), Leica, Stereoscan 440. The images obtained by SEM are in the micrometer range with samples in vacuo.

The Atomic Force Microscope (AFM) provides images of the nanometrical morphology of the surface in environmental atmosphere. The used microscope was a JEOL JSPM in tapping mode. The vibrating frequency of the cantilever was typically in the range of $350 \mathrm{kHz}$. All studies were carried out at room temperature $\left(25 \pm 0.1^{\circ} \mathrm{C}\right)$ in air. Images were recorded in both, height and amplitude modes.
Infrared spectroscopy was chosen to explore changes in the functional chemical groups. A Perkin Elmer Series spectrophotometer model 6X was operated in the ATR-FTIR mode with a resolution of $2 \mathrm{~cm}^{-1}$ and the spectra were interpreted comparing with Pretsch et al. (1980).

\section{Results}

\section{Elemental composition}

Two techniques were used to determine elemental composition, on the one hand conventional X-ray fluorescence (XRF) which is a semi-quantitative analysis and is only valid for elements heavier than $\mathrm{Cl}$ and, on the other, neutron activation analysis (NAA) which is very precise as very low percentages, traces, may be determined. We first obtained by $\mathrm{XRF}$ the average composition ordered by increasing percentage. Sodium, manganese, potassium, zinc and magnesium amounts determined by XRF are presented in Table 1 and compared to NAA results. $\mathrm{Br}, \mathrm{Cr}, \mathrm{Co}, \mathrm{Se}, \mathrm{Ba}, \mathrm{Cu}$ and $\mathrm{Ni}$ were also detected with NAA but they were not quantified.

Table 1. Chemical elements determined by $\mathrm{X}$ ray fluorescence (XRF) and neutron activation analysis (NAA). Trace elements obtained in XRF are labeled as T.E. Elementos químicos determinados por fluorescencia de rayos $X(X R F)$ y análisis por activación neutrónica (NAA). Los elementos identificados a nivel de trazas por XRF se etiquetaron como T.E.

\begin{tabular}{|c|c|c|}
\hline Sample & $\begin{array}{c}\text { XRF } \\
\text { (semiquantitative) }\end{array}$ & $\begin{array}{l}\text { NAA } \\
(\mu \mathrm{g} / \mathrm{g})^{*}\end{array}$ \\
\hline FemCont & $\begin{array}{c}\mathrm{S}, \mathrm{Ca}, \mathrm{P} \\
\mathrm{T} . \mathrm{E}=\mathrm{Zn}, \mathrm{Cl}, \mathrm{Si}, \mathrm{Ni}, \\
\mathrm{Cu}, \mathrm{K}\end{array}$ & $\begin{array}{c}\mathrm{Na}=52 \mathrm{Mn}=13 \\
\mathrm{~K}=29 \mathrm{Zn}=108 \\
\mathrm{Mg}=202\end{array}$ \\
\hline MaleCont & $\begin{array}{c}\text { S, Ca, P } \\
\text { T.E. }=\mathrm{Cl}, \mathrm{Si}, \mathrm{Zn}, \mathrm{Ni} \text {, } \\
\mathrm{Cu}, \mathrm{K}\end{array}$ & $\begin{array}{c}\mathrm{Na}=69 \mathrm{Mn}=19 \\
\mathrm{~K}=47 \mathrm{Zn}=122 \\
\mathrm{Mg}=528\end{array}$ \\
\hline ChildVentIV & $\begin{array}{c}\text { S, K, } \mathrm{Cl}, \mathrm{Ca}, \mathrm{P} \\
\text { T.E. }=\mathrm{Si}, \mathrm{Mn}, \mathrm{Fe}, \\
\mathrm{Mg}, \mathrm{Al}\end{array}$ & $\begin{array}{c}\mathrm{Na}=442 \mathrm{Mn}=82 \\
\mathrm{~K}=0.12 \mathrm{Zn}=53 \\
\mathrm{Mg}=184\end{array}$ \\
\hline ChildVentF2 & $\begin{array}{c}\mathrm{S}, \mathrm{K}, \mathrm{Ca}, \mathrm{Cl}, \mathrm{P} \\
\text { T.E. }=\mathrm{Si}, \mathrm{Zn}, \mathrm{Fe}, \\
\quad \mathrm{Mg}, \mathrm{Al}\end{array}$ & $\begin{array}{c}\mathrm{Na}=473 \mathrm{Mn}=14 \\
\mathrm{~K}=0.13 \mathrm{Zn}=104 \\
\mathrm{Mg}=762\end{array}$ \\
\hline FemAdMuVentV & $\begin{array}{c}\text { S, K, Ca, Cl, P } \\
\text { T.E.=Si, Zn, Al, Mn, } \\
\text { Fe, Mg }\end{array}$ & $\begin{array}{c}\mathrm{Na}=458 \mathrm{Mn}=27 \\
\mathrm{~K}=0.21 \mathrm{Zn}=56 \\
\mathrm{Mg}=350\end{array}$ \\
\hline FemAdMuVentII & $\begin{array}{c}\text { S, Cl, K, Ca, P } \\
\text { T.E.=Si, Fe, Mn, Zn, } \\
\text { Mg, Al }\end{array}$ & $\begin{array}{c}\mathrm{Na}=250 \mathrm{Mn}=66 \\
\mathrm{~K}=0.05 \mathrm{Zn}=93 \\
\mathrm{Mg}=366\end{array}$ \\
\hline
\end{tabular}

* Measurements with an error less than 5\%. 
If the composition of the two contemporary samples (FemCont and MaleCont) is compared, no real difference is found. Both techniques report the same composition. Thus, as the samples are coming from two individuals with different habits, they were not altered by any cosmetical treatments. The samples corresponding to mummified hair present $\mathrm{K}$ and $\mathrm{Cl}$ in the XRF analysis, these elements were not found in the contemporary samples. The amount of sodium in the mummified hair is almost four times higher than in the contemporary. The manganese values are more disperse but two of the mummy samples show that, in the contemporary hair, the content is lower. Such is not the case with potassium, as the content in contemporary hair is 29 to $47 \mu \mathrm{g} / \mathrm{g}$ and in the mummified hair only 0.21 to $0.05 \mu \mathrm{g} / \mathrm{g}$. Zinc oscillates between 53 and $104 \mu \mathrm{g} / \mathrm{g}$ in mummies, it is around $50 \%$ higher in contemporary individuals (108 to $122 \mu \mathrm{g} / \mathrm{g}$ ). Lastly, there is no clear difference in the content of this element between mummified or contemporary hair.

To summarize, hair elemental composition in actual individuals is rather constant and it does not seem to depend significantly on gender. Mummies have a much higher content of sodium, and manganese. Instead, they have a lower percentage of potassium and zinc. All samples presented more magnesium than zinc, especially the child mummies. Still, as the number of samples is low such remarks have no statistical value and have to be confirmed.

\section{Compounds}

$\mathrm{X}$-ray diffraction is the technique used to determine compounds. It requires a crystalline powder. To be observed in a mixture, the compound amount has to be higher than $3 \%$ and the crystallite size larger than $3 \mathrm{~nm}$. Hair, of course, is a non crystalline compound hence no X-ray diffraction peaks should appear in the X-ray diffraction patterns. In our X-ray diffraction patterns, the observed peaks have to be attributed to crystalline compounds present in earth or formed in sick hair. To discriminate between the elements and compounds present in hair and the compounds due to the environment such as clays or sand, and to understand the high percentages found for some elements in the mummy hairs, small samples of soil, close to the corpses, were studied. Samples ChildVentIV, FemAdMuVent5 and FemAdMuVentII come from the same cave whose soil is quartz enriched $\left(\mathrm{SiO}_{2}\right)$. Muscovite, albite, labradorite and some calcite (calcium carbonate) were also identified in the X-ray diffraction patterns, Figure 1. Sample ChildVentF2 environmental soil has as main compound calcite, still some albite and montmorillonite were found.

\section{Morphology}

All samples, as expected, turned out to be filaments whose external surface was a layer of parallel scales. In Table 2, the diameter of each hair sample and the mean separation between

Table 2. Diameter and separation between scales in mummy and reference hairs.

Diámetro y separación de las escamas en pelos de momia y muestras de referencia.

\begin{tabular}{ccc}
\hline Sample & $\begin{array}{c}\text { Diameter } \\
(\mu \mathrm{m})\end{array}$ & $\begin{array}{c}\text { Scale Separation } \\
(\mu \mathrm{m})\end{array}$ \\
\hline FemCont & 87 & 5.0 to 10.0 \\
MaleCont & 87 & 2.0 to 8.0 \\
ChildVentIV & 70 & 7.5 to 10.0 \\
ChildVentF2 & 75 & 7.5 to 10.0 \\
FemAdMuVentV & 92 & 5.0 to 10.0 \\
FemAdMuVentII & 80 & 5.0 to 7.0 \\
\hline
\end{tabular}

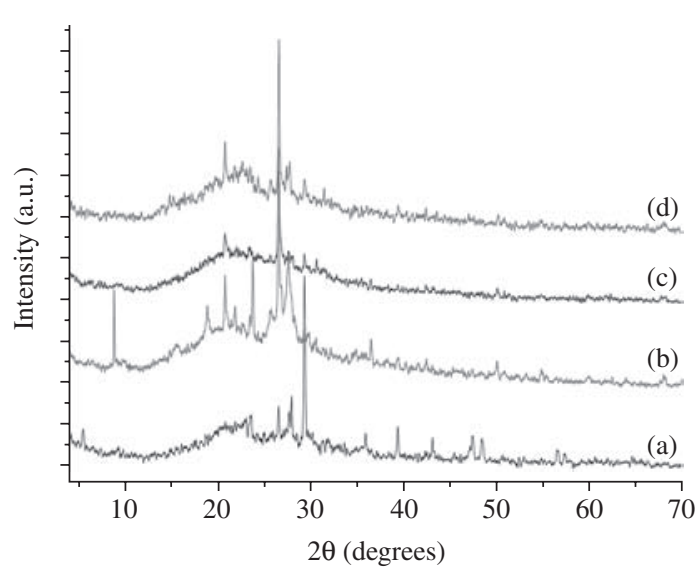

Figure 1.X-ray diffraction patterns of mummy hairs, (a) sample ChildVentF2, (b) ChildVentIV, (c) FemAdMuVent5 and (d) FemAdMuVentII. They all present soil compounds: quartz $\left(\mathrm{SiO}_{2}\right)$, calcite $\left(\mathrm{CaCO}_{3}\right)$ and albite $\left(\mathrm{NaAlSi}_{3} \mathrm{O}_{8}\right)$, in sample ChildVentIV a micaceous compound was also identified.

Patrones de difracción de rayos $X$ de las muestras de pelo de momias (a) ChildVentF2, (b) ChildVentIV, (c) FemAdMuVent5 $y$ (d) FemAdMuVentII. Todos los difractogramas presentaron compuestos del suelo: cuarzo ( $\left.\mathrm{SiO}_{2}\right)$, calcita $\left(\mathrm{CaCO}_{3}\right)$ y albita $\left(\mathrm{NaAlSi}_{3} \mathrm{O}_{8}\right.$ ), en la muestra ChildVentIV también se identificó un compuesto tipo mica. 
scales are compared, as determined by scanning electron microscopy (SEM). The size and scale separation, in both, contemporary and mummy, hairs are similar.

The homogeneity and smoothness of the surface, as well as the regularity of hair in contemporary hair, samples FemCont and MaleCont have to be contrasted with the mummy hair. Often, small particles are adhered on the surface, samples FemAdMuVentV and FemAdMuVentII, Figure 2. In FemAdMuVentV sample, a soil layer covers the hair surface; see the superior section of the image. This layer is interrupted in the lower section of the image revealing the preserved scales. Such observation is in agreement with the elemental composition obtained which includes the contribution of soil incorporated to hair and with the X-ray diffraction patterns. Instead, in sample FemAdMuVentII the erosion has separated a longitudinal fraction of scales showing the concentric structure of hair. On the edge the partial separation of keratinized scales is visible. Furthermore, the scale covering of hair is, partially, distorted. The inner part of hair has disappeared. Indeed, the least structurally robust components collapse first, as they afford the lower resistance to microbial/chemical attack as previously shown (Wilson 2007).

To check that the adhered particles were coming from earth, an EDS analysis was performed. This type of analysis is elemental and local. In Figure 3, the local composition of two samples (FemAdMuVentV and FemAdMuVentII, zones with particles) is compared to the female contemporary hair (FemCont). Clearly, the high amounts of $\mathrm{Si}, \mathrm{Na}$, and $\mathrm{Ca}$, already reported in the previous analysis have to be attributed to the large adhered particles whose size distribution, as shown by the SEM micrographs, is very broad $(0.5$ to $40 \mu \mathrm{m})$. This composition agrees with the $\mathrm{X}$-ray diffraction patterns already presented.

In an effort to characterize the detailed arrangement of the building units of hair, the samples were studied with atomic force microscopy (AFM). This type of microscope can provide, in air,
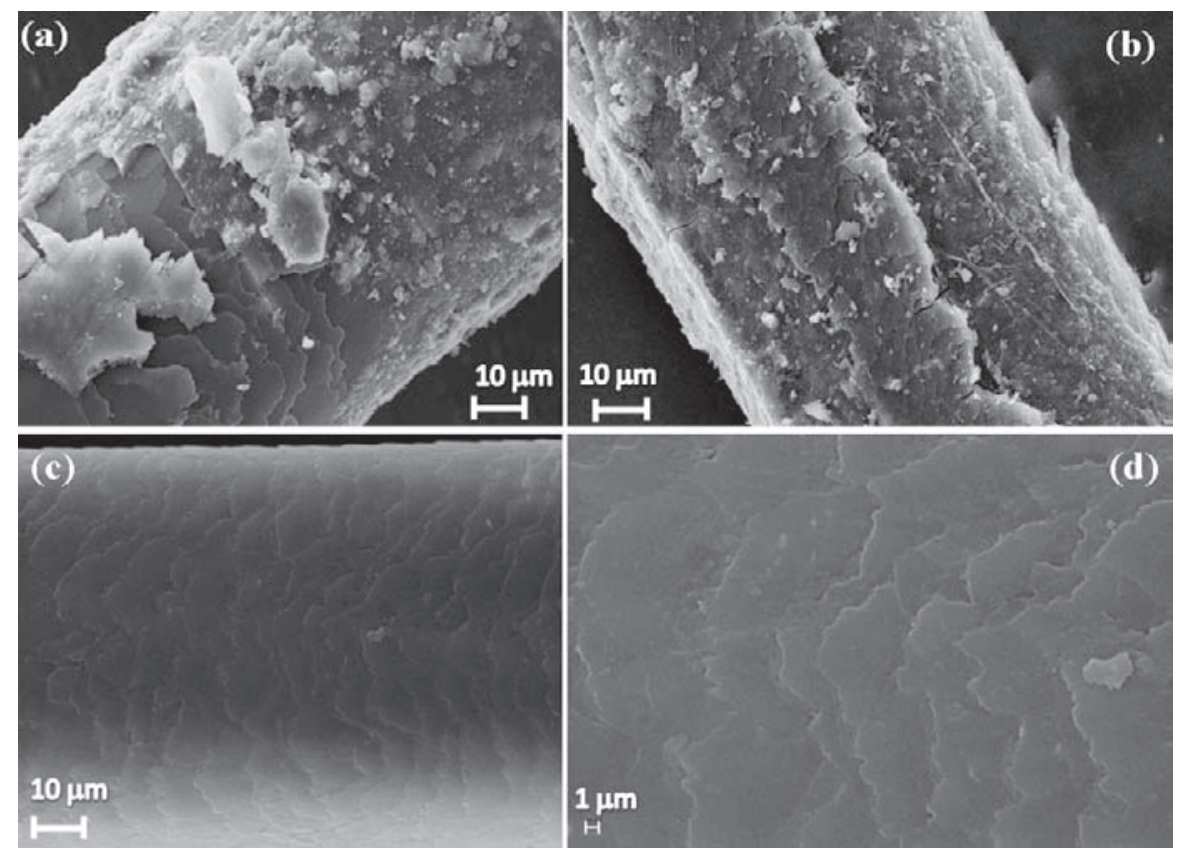

Figure 2. SEM images of the particles adhered on hair surface (a) sample FemAdMuVentV (magnification: x1000) and b) sample FemAdMuVentII (x1000). Note how the scales are totally covered by soil in the upper part of the picture a) and how the hair cuticle pattern is maintained although the hair is degraded, image, (b). Images (c) and (d) correspond to contemporary hair, MaleCont sample, at two different magnifications (x1000 and x2500).

Imágenes SEM de las partículas adheridas en la superficie del cabello (a) muestra FemAdMu VentV (aumento: x1000) y (b) muestra FemAdMu VentII (x1000). Observe cómo las escamas están totalmente cubiertas por partículas de polvo en la parte superior de la imagen (a) y cómo el patrón de la cutícula del cabello se mantiene aunque el pelo se deteriore, imagen (b). Las imágenes (c) y (d) corresponden a pelo contemporáneo, muestra MaleCont, en dos diferentes aumentos (x1000 y x2500). 

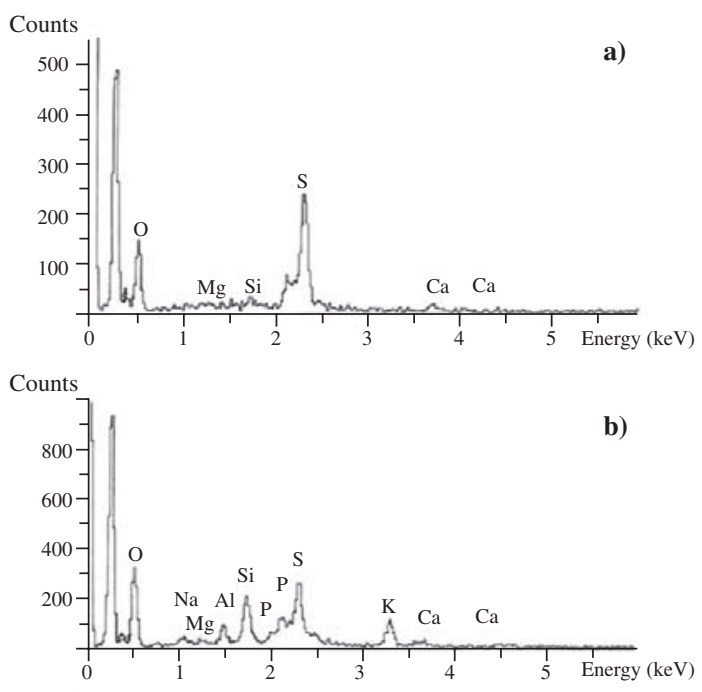
Counts

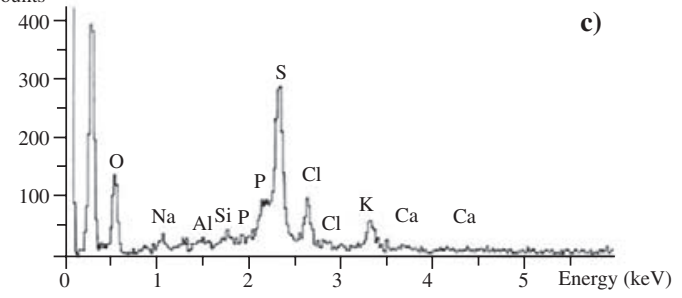

Figure 3. EDS local composition of samples (a) FemAdMuVentV, (b) FemAdMuVentII and (c) FemCont. In EDS spectrum of sample FemAdMuVentV, the composition corresponds to soil elemental analysis.

Composición local, determinada por EDS, de las muestras (a) FemAdMu VentV, (b) FemAdMu VentII y (c) FemCont. El espectro EDS de la muestra FemAdMu VentV, corresponde a la composición elemental del suelo. a surface study at the nanometrical range of sizes. It is complementary to SEM, whose micrographs correspond to micron sizes and samples which are in vacuum and covered with gold.

\section{Nanometrical morphology}

Figure 4 shows that scales are clearly observed with this technique. The scale sizes reported previously by SEM are confirmed. In SEM the roughness of the surface was not so evident, instead, in these images the assembly and shape of scales is clear in environmental conditions as these samples were not gold covered nor in vacuum. Hair surface is known to be covered by a compact hydrophobic layer, the epicuticle, mainly made of fatty acid chains. In sample FemAdMuVentV the environment effect seems to have been stronger as the scales are much more polar due to erosion and they are not in the smooth arrangement found in contemporary hair, Figure $4 \mathrm{c}$. The very high dryness is evident if this image is compared to those reported previously (Dupres 2004) for contemporary hair with different stages of wetting. The images are fuzzy and the edge of scales is rather faded, as in Figure 2 c. Instead, in mummy ChildVentF2, the scales have remained ordered as tiles. If the magnification is increased, a nano-morphology is observed, Figure 5. A hole appears in the lower part of the image whose diameter is $20-30 \mathrm{~nm}$.
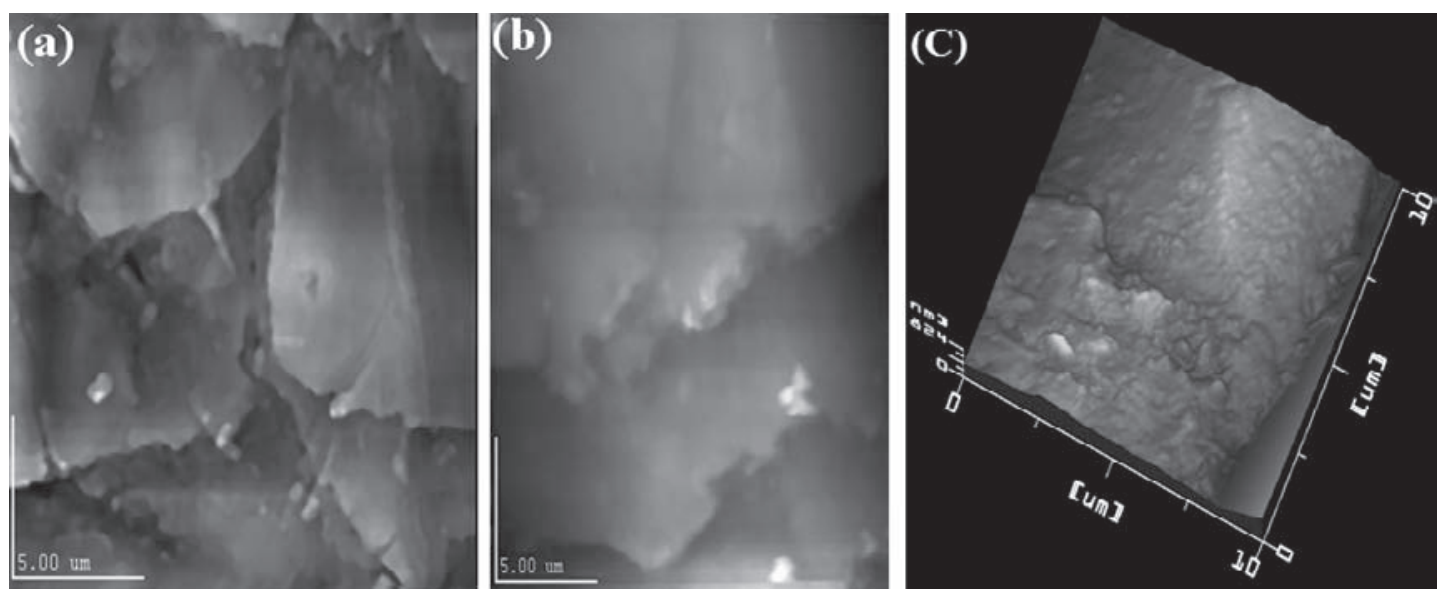

Figure 4. Atomic force microscopy image of the (a) FemAdMuVent5 and (b) ChildVentF2 sample surfaces, showing the scales already observed by SEM compared to contemporary hair (c) MaleCont sample.

Imagen de microscopía de fuerza atómica de las superficies de las muestras FemAdMu Vent5 (a) y ChildVentF2 (b), mostrando las escamas observadas por SEM. Se comparan con la muestra de cabello MaleCont contemporánea (c). 


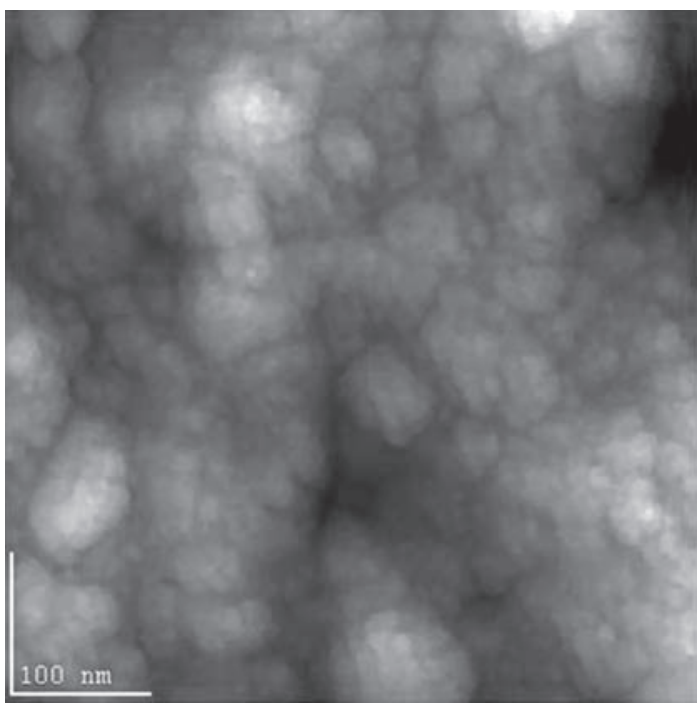

Figure 5. Atomic force microscopy image of the ChildVentF2 sample surface where the constituting cells can be observed. Imagen de microscopía de fuerza atómica de la superficie de la muestra ChildVentF2.

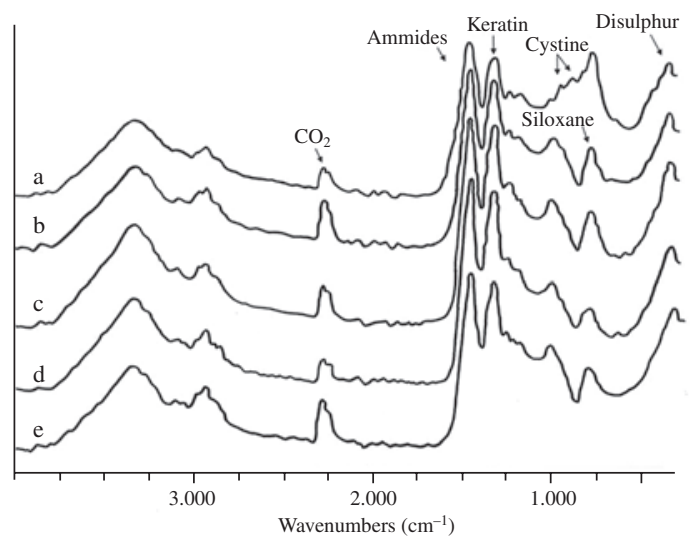

Figure 6. Infrared spectra of contemporary hair: (a) sample MaleCont and (b) sample FemCont compared to mummy hairs: (c) sample ChildVentIV, (d) sample FemAdMuVentII and (e) sample FemAdMuVent5.

Espectros infrarrojos de pelo contemporáneo MaleCont (a) y FemCont (b) y pelos de momia: (c) ChildVentIV, (d) FemAdMu VentII y (e) FemAdMu Vent5.

\section{Chemical species}

Infrared spectroscopy (ATR-FTIR) is useful to identify some functional chemical groups, associated to the material surface. The spectra exhibited in Figure 6, show a band at $2350 \mathrm{~cm}^{-1}$ which can be assigned to species $\mathrm{CO}_{2}$ or $\mathrm{CO}_{3}{ }^{2-}$. These species came from either $\mathrm{CO}_{2}$ from air or carbonates present in the place where the mummies were stored.
However, note that contemporary samples exhibit also these bands, and then absorption is due to $\mathrm{CO}_{2}$ present in air. It is worth nothing that bands due to stretching $\mathrm{Si}-\mathrm{H}$ bonds are also expected to appear close to $2,300 \mathrm{~cm}^{-1}$. However these absorptions are generally accompanied of a little change in a dipole moment and then are expected to be weak intense bands. Bands at 1,800 and 1,500 $\mathrm{cm}^{-1}$ present in all samples may be attributed to amides and keratin. Note that this attribution is made because chemical species are not isolated. Actually, amides present in pure molecules absorb, for example, close to $1,600 \mathrm{~cm}^{-1}$. However, note that amides as a part of stable structure of hair should be interacting by hydrogen bonds, then bonds of amine could became weaker and then absorption frequencies shifts to lower values. The band at $1,050 \mathrm{~cm}^{-1}$ can be attributed to siloxane and lastly the disulphide band is at $750 \mathrm{~cm}^{-1}$. These results show that mummy hairs are similar in composition to the contemporary reference.

Still, sample FemAdMuVentV is different as it presents two bands, at 1,200 and $1,130 \mathrm{~cm}^{-1}$, which are due to cystine. Cystine is an aminoacid present in many proteins, and it is commonly found in hair. It is a long molecule composed by two similar sections united by terminal sulphur atoms. In presence of a reductor agent, the two sections separate and provide two cystine molecules which assembly again in presence of an oxidant. This double reaction is often used in to wave and blanching hair (Hilterhaus-Bong 1987) with FTIR spectroscopy it has been found that, during oxidation, disulphide bonds in the hair keratin were cleaved and two sulphonic acid residues were produced. The degradation product observed at $1,044 \mathrm{~cm}^{-1}$ was, then, cysteic acid which formed as a result of this process.

\section{Discussion}

The comparison of elemental composition results, obtained by neutron activation analysis or by X-ray fluorescence, shows differences. The amount of sodium and manganese is much higher in mummies than in contemporary individuals in agreement with Casallas et al. (2003) who suggest mummy hair absorption of some elements from the surrounding soil. Still, values may change in a very large interval. To understand the differences in potassium content depending on the two techniques, 
it has to be noted that hair was washed before neutron activation analysis but not for X-ray fluorescence. Still, Casallas et al. (2003) found that cleaning hair before analysis does not completely remove contamination (Cartmell and Weems 2001). It is accepted that a normal hair sodium/potassium ratio should be between 2.5:1.0 and 4.0:1.0 (Wilson 2008); the contemporary individuals have a ratio, as determined by neutron activation technique, of 1.8:1.0 (sample FemCont) and 1.5:1.0 (sample MaleCont), this improbable result shows how washing may provide misleading results (Assarian 1977).

But, if mummy samples are not washed the analyses correspond as well to hair as to the adherence of exogenous elements. This remark explains the unusually high amounts of sodium obtained in mummy hairs, even washed. Sodium and calcium are often present in soil components as clays or other minerals, already determined in this study by $\mathrm{X}$-ray diffraction and observed by SEM.

SEM images confirm this interpretation as small pieces of adhered minerals were observed with mummy hair. In sample FemAdMuVentV, hair is homogeneously covered by a layer of soil. Micrographs of contemporary hair are typical and can be compared with those presented in previous papers (Lira Eyzaguirre 2002; Meyer 2002 and Poletti 2003). Determining the diameter of human hair is not straightforward due to hair ellipticity, variability between hairs on a head and along an individual fiber. Furthermore, it depends on the person age, the lowest values are found in children; they rise to a peak in early adulthood and decline gently thereafter. The age-related decline in mean hair diameter may be due to a fall in the number of large diameter hairs rather than a reduction in the size of individual hairs (Birch 2001). Wortmann and Schwan-Jonczyk (Wortmann 2006) have measured the fiber diameters by Optical Fibre Diameter Analyser and by weighting. The Wortmann and Schwan-Jonczyk values of contemporary hair are comprised in the interval 74.5 to $96.1 \mu \mathrm{m}$. The contemporary samples of our study had a diameter of $87.0 \mu \mathrm{m}$ which fits into the expected values. The mummy hair diameters are comprised between 70.0 and $92.5 \mu \mathrm{m}$. As the mummy hair is eroded or has minerals stuck to it, the value may be exaggerated or diminished depending on the measurement zone.

The hair external layer is constituted by cuticle scales observed by scanning electron microscopy and atomic force microscopy. The thin cell membrane layer, also referred to as the epicuticle, consists of a protein matrix and a lipid layer which strongly contribute to the hydrophobicity and lubricity of virgin hair (Lodge 2006). This fatty acid is intact in the virgin hair, contemporary samples, but is removed in the mummy hair causing a slightly hydrophilic and less lubricious surface. The scales as shown by atomic force microscopy turn out to be, then, less ordered but well preserved. Note that, in ancient Egyptian mummies, bulk keratin structure has not been modified significantly over 2000 years; although, a partial disorganization of keratins close to the hair surface through polypeptide bond breakage is observed (Bertrand 2003).

The presence of a pore in sample FemAdMuVentV is relevant as a similar feature has been reported by Smith and Swift (Smith 2002). The small holes they report were found on the cuticular surface and have a diameter of $107.0 \mathrm{~nm}$ and depth of $6.0 \mathrm{~nm}$. In our sample the size is close to $30.0 \mathrm{~nm}$. Such holes are attributed to a chemical attack of the protein under the cuticle overhang. In this way, FTIR results of this sample agree with this attack as disulfide bonds cleavage makes a soluble protein that could be easily extracted. The environmental attacking species are then able to diffuse before causing pit formation in the underlying protein. Another possibility could be that the attacking species are generated in the post mortem tissues undergoing decomposition changes attributed to microbial and autolytic actions. Morphological changes occur, then, in hair roots (Roberts 2007). Such hypothesis may be supported by Figure $2 \mathrm{~b}$ where the disintegration of the hair core explains the deformation of the scales layer. Furthermore, infrared spectra show that in this sample cystine has reacted.

Wilson et al. (2001) demonstrate a breakdown of cortical cell boundaries and disruption of the cuticular layering, coupled with infiltration of material from the burial matrix. These authors suggest that there is a progressive loss of cohesion that is in part due to microbiological activity. Medullated hair is shown to be in this study more susceptible to physical breakdown by providing two routes for microbial and environmental attack. At the molecular level the proteinaceous component undergoes alteration, and the S-S cystine linkages, responsible for the strength and resilience of hair in living individuals, are lost. 


\section{Conclusion}

The comparison between contemporary and mummy hair has shown that mummy hair can be preserved in cave conditions although it may interact with environmental dirt or soil. Our results have shown that clays may cover the hair fibers and constitute a protective film. As degradation of hair initiates in the core, scales are rather well preserved. We have shown that degradation is due on the one hand to the reaction of cystine and on the other to the partial collapse of the scale arrangement. The scales become less ordered and the hair surface less smooth. Thus, only a characterization at a nanometrical level can be used to propose hair degradation mechanisms which are, indeed, due to chemical reactions.
The combination of several physical and chemical techniques is crucial to describe the various aspects of hair characteristics and their evolution with time. In this work, the atomic force microscopy has provided the morphological description of the samples at a nanometrical level. The features found in mummy hair suggest that the correlation between chemical composition and health or nutrition of ancient people should be carefully evaluated due to environmental contamination.

Acknowledgements: The SEM, and X-ray diffraction work of José Chávez and Leticia Baños respectively is gratefully recognized as well as the expertise of the group of the IIM-library.

\section{References Cited}

Assarian, G.S., and D. Oberleas

1977 Effect of washing procedures on trace-element content hair. Clinical Chemistry 23:1771-1772.

Aufderheide, A.C.

2003 The Scientific Study of Mummies. Cambridge University Press, Cambridge.

Bertrand, L., J. Doucet, P. Dumas, A. Simionovici, G. Tsoucaris, and P. Walter

2003 Microbeam synchrotron imaging of hairs from ancient Egyptian mummies. Journal of Synchrotron Radiation 10:387-392.

Birch, M.P., J.F. Messenger, and A.G. Messenger

2001 Hair density, hair diameter and the prevalence of female pattern hair loss. British Journal of Dermatology 144:297-304.

Cartmell, L. W., and C. Weems

2001 Overview of hair analysis: A report of hair analysis from Dakhleh Oasis, Egypt Chungara 33:289-292.

Casallas, R., N.F. Mangelson, M.C.J. Kuchar, C.W. Griggs, and L.B. Rees

2003 Trace element analysis of ancient hair: A word of caution. Mummies in a new millennium. Proceedings of the $4^{\text {th }}$ world congress on mummy studies. Nuuk, Greenland, Greenland National Museum and Archives and Danish Poñar Center: 72-75.

Du, A.Y., N.F. Mangelson, L.B. Rees, and R.T. Matheny 1996 PIXE elemental analysis of South American mummy hair. Nuclear Instruments and Methods in Physics Research Section B 109/110:673-676.

Dumestre-Toulet, V., V. Cirimele, B. Ludes, S. Gromb, and P. Kintz

2002 Hair analysis of seven bodybuilders for anabolic steroids, ephedrine, and clenbuterol. Journal of Forensic Sciences 47:211-214.

Dupres, V., T. Camesano, D. Langevin, A. Checco, and P. Guenoun 2004 Atomic force microscopy imaging of hair: correlations between surface potential and wetting at the nanometer scale. Journal of Colloid and Interface Science. 269:329-335.
Gilbert, M. T. P., and A.S. Wilson

2006 Hair and nail. In Forensic Human Identification, edited by T. Thompson, and S. Black, pp. 147-174. CRC Press, Boca Raton.

Hilterhaus-Bong, S., and H. Zahn

1987 Contributions to the chemistry of human hair. I. Analyses of cystine, cysteine and cystine oxides in untreated human hair. International Journal of Cosmetic Science. 9:101-109.

Lira Eyzaguirre, M.P.

2002 Análisis científico de fibras arqueológicas. Conserva 6:47-59.

Lodge, R.A., and B. Bhushan

2006 Surface characterization of human hair using tapping mode atomic force microscopy and measurement of conditioner thickness distribution. Journal of Vacuum Science and Technology A 24:1258-1269.

Macko, S.A., and M.H. Engel

1998 in Stephanie Pain. Beyond the fringe, 2164 of New Scientist magazine, 12 December 1998, page 34

Meaglia D., E. Costa, F. Barbero, and E.R. Massa

2006 Archaeological hair in paleobiological research. Proceedings V World Congress on Mummy Studies. Journal of Biological Research 80:110-113.

Meyer W., A. Schnapper, and G. Hülmann

2002 The hair cuticle of mammals and its relationship to functions of the hair coat. Journal of the Zoological Society of London 256:489-494.

Monteiro, V.F., A.P. Maciel, and E. Longo 2005 Thermal analysis of Caucasian human hair. Journal of Thermal Analysis and Calorimetry 79:289-293.

Nowak, B.

1996 Occurrence of heavy metals, sodium, calcium, and potassium in human hair, teeth, and nails. Biological Trace Element Research 52:11-21.

Poletti G., F. Orsini, C. Lenardi, and E. Barborini 2003 A comparative study between AFM and SEM imaging on human scalp hair. Journal of Microscopy. 211:249-255. 
Pretsch, E., T. Clerc, J. Seibl, and W. Simon

1980 Tablas para la Elucidación Estructural de Compuestos Orgánicos por Métodos Espectroscópicos. Ed. Alambra, Madrid.

Roberts, K.A., and C. Calloway

2007 Mitochondrial DNA amplification success rate as a function of hair morphology. Journal of Forensic Sciences 52:40-47.

Sandford, M.K., and G.E. Kissling

1993 Chemical analyses of human hair: anthropological applications. In Investigations of Ancient Human Tissue, Chemical Analyses in Anthropology, edited by Mary K. Sandford, pp. 131-166. Gordon and Breach Science Publishers, Amsterdam.

Smith, J.R., and J.A. Swift

2002 Lamellar subcomponents of the cuticular cell membrane complex of mammalian keratin fibres show friction and hardness contrast by AFM. Journal of Microscopy 206:182-193.

Thibault S. and B. A. Bernard

2005 The biology of hair shape. International Journal of Dermatology 44:2-3.
Wilson, L.

2008, High Sodium/Potassium Ratio http://www.drlwilson. com/Articles/sodium-potassium\%20high.htm (accessed April 17, 2009).

Wilson, A.S., R.A. Dixon, H.G.M. Edwards, D.W. Farwell, R.C. Janaway, A.M. Pollard, and D.J. Tobin

2001 Towards an understanding of the interaction of hair with the depositional environment. Chungara Revista de Antropología Chilena 33:293-296.

Wilson, A.S., H.I. Dodson, R.C. Janaway, A.M. Pollard, and D.J. Tobin

2007 Selective biodegradation in hair shafts derived from archaeological, forensic and experimental contexts. British Journal of Dermatology 154:450-457.

Wortmann, F.J., and A. Schwan-Jonczyk

2006 Investigating hair properties relevant for hair 'handle'. Part I: hair diameter, bending and frictional properties. International Journal of Cosmetic Science 28:61-68. 